\title{
GOBERNANZA EN LA GESTIÓN INTEGRAL DE RECURSOS HÍDRICOS EN LAS SUBCUENCAS RÍO SABINAL Y CAÑÓN DEL SUMIDERO EN CHIAPAS, MÉXICO
}

\section{GOVERNANCE IN THE INTEGRAL MANAGEMENT OF WATER RESOURCES IN THE RIO SABINAL AND CAÑON DEL SUMIDERO WATERSHEDS IN CHIAPAS, MEXICO}

\author{
Verónica Gutiérrez-Villalpando ${ }^{1^{*}}$, Emma Zapata-Martelo ${ }^{2}$, Austreberta Nazar-Beutelspacher ${ }^{3}$, \\ Benito Salvatierra-Izaba ${ }^{3}$, Celia Ruíz-de Oña ${ }^{4}$ \\ ${ }^{1}$ Catedrática del CONACYT, comisionada en el Colegio de Posgraduados, Campus Puebla \\ (vgutierrez@conacyt.mx).르olegio de Postgraduados, Campus Montecillo (ezapata@colpos. \\ mx). ${ }^{3}$ El Colegio de la Frontera Sur (anazar@ecosur.mx, bsalvati@mail.ecosur.mx). ${ }^{4}$ Universidad \\ Nacional Autónoma de México PROIMSE-UNAM (celiardo@unam.mx).
}

RESUMEN

Se analizan los procesos de gobernanza del agua de las subcuencas Río Sabinal y Cañón del Sumidero en Chiapas, México, con el objetivo de ofrecer una visión de conjunto de los principales problemas que las afectan y los mecanismos para abordarlos. Se utiliza el enfoque metodológico denominado Marco Analítico de la Gobernanza (Hufty, 2004) para dar cuenta de tres experiencias de gobernanza del agua que aglutinan a un nutrido grupo de actores. Se abordan cinco dimensiones analíticas: definición del problema, nodos o espacios de interacción, actores, normas y procesos de interacción, valorando a los sectores involucrados en la construcción de una gobernanza del agua participativa y efectiva.

Palabras clave: agua, gobernanza, gestión integral, cuenca, puntos nodales, sustentabilidad.

\section{INTRODUCCIÓN}

$\mathrm{L}$ a concepción del agua como recurso hídrico ha sufrido una transformación sustancial; hoy se reconoce que los componentes de los ecosistemas acuáticos son los que permiten satisfacer la demanda de agua para distintos propósitos en una cuenca, como insumo de producción y factor relevante para la conservación de la biodiversidad (Retamal et al., 2013). Una disminución en la integridad de la cuenca como ecosistema genera el deterioro de servicios ecosistémicos, a lo cual se suma el impacto del cambio climático sobre el ciclo hidrológico y los sistemas de gestión de agua (White et al., 2008).

\footnotetext{
* Autor responsable * Author for correspondence.

Recibido: septiembre, 2016. Aprobado: agosto, 2017.

Publicado como ARTÍCULO en ASyD 16: 159-181. 2019.
}

\begin{abstract}
This study analyzes the processes of water governance in the Rio Sabinal and Cañon del Sumidero watersheds in Chiapas, Mexico, with the goal of providing an overarching vision of their principal structural problems, as well as the mechanisms of governance designed to address them. Using the Governance Analytical Framework (GAF) set forth by Hufty (2004), it analyzes three distinct water governance scenarios in which numerous governmental and non-governmental actors come together. Five analytical dimensions are employed: problem definition, interaction nodes or spaces, actors, norms or mechanisms of regulation and interactive processes - to evaluate the efficacy of the various sectors in constructing an effective and participative water governance system.
\end{abstract}

Key words: water, governance, integral management, watersheds, nodal points, sustainability.

\section{INTRODUCTION}

$\mathrm{T}$ The conception of water as a water resource has suffered a substantial transformation; today it is recognized that the components of aquatic ecosystems are those that allow satisfying the water demand for different purposes in a basin, as an input of production and relevant factor for the conservation of biodiversity (Retamal et al., 2013). A decrease in the integrity of the basin as an ecosystem generates the deterioration of ecosystemic services, to which the impact of climate change on the hydrological cycle and the water management systems is added (White et al., 2008).

Retamal et al. (2013) point out that in order to face these challenges, new forms of governing ecosystem goods and services provided by basins are 
Retamal et al. (2013) señalan que para enfrentar estos desafíos son necesarias nuevas formas de gobernar los bienes y servicios ecosistémicos que proveen las cuencas (Kallis et al., 2009), a través de una gobernabilidad sustentable del agua.

El término "gobernanza del agua" es un concepto en construcción. La Asociación Mundial del Agua (GWP-Global Water Parthership) la define como "el grupo de sistemas políticos, sociales, económicos y administrativos que están en posibilidad de desarrollar y administrar recursos hídricos y distribuir los servicios del agua en los diferentes niveles de la sociedad" (Martínez y Reyna, 2012), mientras que la Organización para la Cooperación y el Desarrollo Económicos (OCDE, 2011) hace una distinción entre gobernanza y gestión del agua, al definir a esta última como "las actividades operacionales para el cumplimiento de objetivos específicos, entre ellos abastecimiento de agua, consumo y reciclaje”. Así, podría concluirse que la gobernanza del agua hace referencia al marco político-administrativo en el que se define el uso del agua (quiénes deciden), en tanto que la gestión del agua tiene que ver con los requerimientos físicos para su distribución (infraestructura administrativa y técnica) (Martínez y Reyna, 2012).

La faceta más explorada de este concepto ha sido el análisis de formas comunitarias de gestión del agua, considerándola como bien común (Ostrom, 2000). Estas acepciones están referidas al ejercicio del gobierno, o bien, a la forma de autogobierno de una comunidad; describen y explican la descentralización que caracteriza el actual proceso de dirección de la sociedad, la multipolaridad y su carácter de sistema (Aguilar, 2007), resultado de cambios en las estructuras, los procesos de gobierno y las nuevas maneras de concebir a este (Waylen, 2008). Por su parte, Paz (2012) define la gobernanza como la interacción cooperativa y responsable de actores gubernamentales y no gubernamentales, sociales y privados, en la construcción de política pública.

En el Sexto Foro Mundial del Agua, una de las principales conclusiones fue que "las sociedades enfrentan una crisis en el manejo del agua, misma que podría caracterizarse como una crisis de gobernanza" (Martínez y Reyna, 2012).

Para Murillo (2012), la gobernanza del agua conlleva dos modos de aplicación: el impulso de la participación social y los mecanismos de negociación entre los proyectos sociales y los institucionales- necessary (Kallis et al., 2009), through sustainable water governance.

The term "water governance" is a concept under construction. The Global Water Partnership (GWP) defines it as "the group of political, social, economic and administrative systems that have the possibility of developing and managing water resources and distributing water services at different levels of society" (Martínez and Reyna, 2012), while the Organisation for Economic Co-operation and Development (OECD, 2011) makes a distinction between governance and management of water, by defining the latter as "the operative activities for the fulfillment of specific objectives, among them water supply, consumption and recycling". Therefore, it could be concluded that water governance refers to the political-administrative framework within which water use is defined (who decides), while water management is related to the physical requirements for its distribution (administrative and technical infrastructure) (Martínez and Reyna, 2012).

The most explored facet of this concept has been the analysis of community forms of water management, considering it as a common good (Ostrom, 2000). These meanings refer to the exercise of government, or else, to the form of selfgovernment of a community; they describe and explain the decentralization that characterizes the current direction process of society, multi-polarity, and its nature as a system (Aguilar, 2007), resulting from changes in the structures, government processes, and the new ways of conceiving it (Waylen, 2008). In turn, $\operatorname{Paz}$ (2012) defines governance as the cooperative and responsible interaction of governmental and non-governmental actors, social and private, in the construction of public policy.

In the Sixth Global Water Forum, one of the main conclusions was that "societies face a crisis in water management, which could be characterized as a crisis of governance" (Martínez and Reyna, 2012).

For Murillo (2012), water governance entails two modes of application: the promotion of social participation and the mechanisms of negotiation between social and institutional-government projects, and the institutional performance and rules and regulations that arise from formal institutionalism. In this sense, the governability of water is focused on the hierarchically built authority (vertically), while water governance looks for consensus, negotiation 
gubernamentales, y el desempeño institucional y las normas y reglas desde la institucionalidad formal. En este sentido, la gobernabilidad del agua se enfoca en la autoridad jerárquicamente construida (verticalmente), mientras que la gobernanza del agua busca el consenso, la negociación y el diálogo (horizontalmente). La gobernanza implica la gestión integrada de los recursos hídricos o gestión por cuencas, como formas eficaces, pero también el reconocimiento de formas de gestión tradicionales para ámbitos locales (Domínguez, 2007).

Más allá del concepto de gobernanza del agua, conviene rescatar la emergencia del discurso de la gobernanza en el ámbito ambiental. De acuerdo con Kooiman (2004), la gobernanza es el conjunto de interacciones entre actores públicos y privados orientadas a resolver sus problemas sociales, con el fin de crear oportunidades en un marco normativo. Tradicionalmente, el campo de la política ambiental y de gestión de recursos naturales ha operado a partir de estrategias jerárquicas de mando y control, aún dominantes (Briggs, 2003; Holling et al., 1996). Sin embargo, en décadas recientes asistimos a la emergencia de nuevas estrategias de interacción entre un amplio rango de actores, políticos y sociales, quienes han empezado a diseñar y experimentar con mecanismos institucionales novedosos, buscando un abordaje más eficiente y legítimo de la interdependencia, complejidad, ambigüedad e incertidumbre características de la problemática ambiental (Bäckstrand, 2010).

Estas transformaciones en la conducción de los asuntos públicos ambientales están relacionadas con cambios más profundos en la naturaleza del Estado, cuya esfera de acción disminuye, de acuerdo con algunos actores, o se transforma, según otros, en facilitador e impulsor de estas experiencias de coordinación para el diseño de política pública (Kooiman, 2004; Mayntz, 2001; Rhodes, 1996; Zurbriggen, 2011).

Agrupadas bajo el término de "nuevos modos de gobernanza ambiental” (Holley et al., 2011; Bäckstrand, 2010), estas estrategias adoptan diferentes configuraciones, pero coinciden en su énfasis en la participación de distintos actores del gobierno para el diseño de políticas ambientales y la toma de decisiones; en la coordinación, tanto sectorial como a través de escalas territoriales; y en el esfuerzo por integrar el conocimiento científico y la experiencia social en el diseño de políticas ambientales, en un afán and dialogue (horizontally). Governance implies the integrated management of water resources or management by basins, as efficient forms, but also the recognition of traditional forms of management for local spheres (Domínguez, 2007).

Beyond the concept of water governance, it is convenient to rescue the emergence of the discourse of governance in the environmental sphere. According to Kooiman (2004), governance is the set of interactions between public and private actors directed at solving their social problems, with the aim of creating opportunities within a normative framework. Traditionally, the field of environmental policy and natural resource management has operated based on hierarchical strategies of command and control, which are still dominant (Briggs, 2003; Holling et al., 1996). However, in recent decades, we have witnessed the emergence of new strategies of interaction between a wide range of actors, political and social, who have started to design and experiment with novel institutional mechanisms, seeking a more efficient and legitimate approach to interdependence, complexity, ambiguity, and uncertainty that are characteristic of the environmental quandary (Bäckstrand, 2010).

These transformations in the conducting of environmental public issues are related to deeper changes in the nature of the State, whose action sphere decreases, according to some actors, or transforms, according to others, into an enabler and driving force of these coordination experiences for the design of public policy (Kooiman, 2004; Mayntz, 2001; Rhodes, 1996; Zurbriggen, 2011).

Grouped under the term of "new modes of environmental governance" (Holley et al., 2011; Bäckstrand, 2010), these strategies adopt different configurations, but they agree in their emphasis on the participation of different government actors for the design of environmental policies and in decision making; in the coordination, both sectorial and through territorial scales; and in the endeavor to integrate scientific knowledge and social experience in the design of environmental policies, in an effort to make them more transparent and democratic (Arts and Leroy, 2006; Holg et al., 2012; Lemos and Agrawal, 2006; Newig et al., 2007). However, governance processes are sustained by the need to establish regulation mechanisms in plural societies, based 
por hacerlas más transparentes y democráticas (Arts y Leroy, 2006; Holg et al., 2012; Lemos y Agrawal, 2006; Newig et al., 2007). Sin embargo, los procesos de gobernanza se sustentan en la necesidad de establecer mecanismos de regulación en sociedades plurales, con base en los principios de la democracia política occidental (Vargas, 2008). En relación con esto, Mayntz (2001) señalaba ciertas condiciones de base estructural e institucional necesarias para que el ejercicio de la gobernanza pudiera desempeñarse, como son la presencia de autoridades políticas legitimadas democráticamente y sólidamente establecidas, así como una dispersión del poder en los diferentes sectores de la sociedad "de manera no fragmentada y eficiente" (Mayntz, 2001: 3). A pesar de que Mayntz admite que estas son condiciones ideales, es importante señalar que la práctica de la gobernanza en América Latina estará condicionada por una estructura sociopolítica a menudo inestable y en diferentes grados de consolidación democrática, en muchos casos con autoridades gubernamentales carentes de legitimidad.

En este estudio se adopta el concepto COLMEXCONAGUA-IMTA-ANEAS propuesto por Domínguez et al. (2012) en su obra "Hacia un posicionamiento de la gobernanza del agua en México", en la que se entiende por gobernanza del agua "los procesos en interacciones entre los sistemas sociales, económicos políticos, ambientales y de gobierno, con el fin de conseguir una visión conjunta sobre el uso y futuro de los recursos hídricos e implementar mecanismos que faciliten su consecución".

Desde las perspectivas de la gobernanza del agua se plantea que la Gestión Integral de los Recursos Hídricos (GIRH) es la forma adecuada de administrar el recurso agua, teniendo como unidad de gestión la cuenca, como se establece en el marco normativo vigente en la Ley de Aguas Nacionales (SEMARNAT, 2004). La GIRH es un proceso que promueve la gestión y el desarrollo coordinados del agua, el suelo y los otros recursos relacionados, con el fin de maximizar los resultados económicos y el bienestar social de forma equitativa, sin comprometer la sostenibilidad de los ecosistemas vitales y en estrecha relación con el "desarrollo sustentable".

Para la aplicación de dicha ley en relación con este concepto, se considera primordialmente agua y bosque (García, 2010). Borquez et al. (2007) mencionan que la problemática actual de la gestión integral de los recursos hídricos tiene su origen en tres factores on the principles of western political democracy (Vargas, 2008). In relation to this, Mayntz (2001) pointed to certain conditions of structural and institutional basis that are necessary for the exercise of governance to be carried out, such as the presence of democratically legitimate and solidly established political authorities, as well as a dispersion of power in the different sectors of society "in a non-fragmented and efficient manner" (Mayntz, 2001: 3). Although Mayntz admits that these are ideal conditions, it is important to point out that the practice of governance in Latin America will be conditioned by a sociopolitical structure that is often unstable and in different degrees of democratic consolidation, in many cases with government authorities that lack legitimacy.

In this study, the COLMEX-CONAGUA-IMTAANEAS concept proposed by Domínguez et al. (2012) in their work "Toward a positioning of water governance in Mexico" (Hacia un posicionamiento de la gobernanza del agua en México) is adopted, where water governance is understood as "the processes in interactions between social, economic, political, environmental and government systems, with the aim of attaining a joint vision about the use and future of water resources and implementing mechanisms that facilitate its achievement".

From the perspectives of water governance, it is suggested that the Integrated Water Resources Management (IWRM) is the adequate form of managing the water resource, with the basin as management unit, as established in the current normative framework of the National Water Law (Ley de Aguas Nacionales) (SEMARNAT, 2004). IWRM is a process that promotes the coordinated management and development of water, soil and other resources related, with the aim of maximizing the economic results and the social welfare in an equitable manner, without compromising the sustainability of vital ecosystems and in close relation with "sustainable development".

For the application of this law in relation to this concept, water and forests are mainly considered (García, 2010). Borquez et al. (2007) mention that the current quandary of integrated water resources management has its origin in three factors that threaten their sustainability: 1) accelerated growth of the population and of economic activity; 2) lack of programs for poverty mitigation, combined with 
que amenazan su sostenibilidad: 1) crecimiento acelerado de la población y de la actividad económica; 2) falta de programas de mitigación de la pobreza, combinados con inequidad socioeconómica; y 3) distribución irregular del agua y escasez en los sectores de mayor demanda.

\section{Marco Analítico de Gobernanza (MAG)}

Hufty (2004) propone un enfoque alternativo para analizar la gobernanza, llamado Marco Analítico de la Gobernanza (MAG), desarrollado en el programa North-South por el Graduate Institute of International and Development Studies de la Universidad de Ginebra, Suiza. Un rasgo central de la metodología son los elementos analíticos o dimensiones observables de la gobernanza: el problema, los actores, las normas sociales, los puntos nodales y los procesos, cuya configuración produce distintos tipos de gobernanza y, por ende, de ciudadanía. Asimismo, Natera (2005) menciona que tanto el capital social como el liderazgo público son condicionantes específicos para garantizar el éxito de la gobernanza a la cual concibe como la acción gubernamental, refiriéndose a la gestión de las redes integradas por una multiplicidad de actores públicos y privados que interactúan de forma compleja y a cuyo análisis se presta la atención preferente.

\section{Contexto de las subcuencas Río Sabinal y Cañón del Sumidero}

Chiapas es una de las entidades con mayores recursos hídricos en México, con una aportación de 40\% del total nacional. En 2005, $71.1 \%$ de las viviendas particulares habitadas contaba con agua entubada (SEDESOL-INEGI, 2005), proporción que aumentó a $73.5 \%$ en 2010 (INEGI, 2010); esto representa un incremento mínimo (2.4\%), muy por debajo del crecimiento de la demanda. En esa entidad existen manantiales que se quedan sin agua durante largos periodos, siendo las mujeres rurales de bajos recursos las más afectadas porque deben acarrearla hacia sus hogares. La falta de agua también se asocia a la deforestación, la degradación de suelos, la contaminación y sobreexplotación de los mantos acuíferos. Ante esta situación se han instrumentado Programas de Ordenamiento Territorial (POET) y planes de emergencia, como en el caso de la Subcuenca Río Sabinal (Gobierno del Estado de Chiapas, 2010). socioeconomic inequity; and 3) irregular distribution of water and scarcity in the sectors of greatest demand.

\section{Governance Analytical Framework (GAF)}

Hufty (2004) proposes an alternative approach to analyze governance, called Governance Analytical Framework (GAF), developed in the North-South program of the Graduate Institute of International and Development Studies at the University of Geneva, Switzerland. A central trait of the methodology is the analytical elements or observable dimensions of governance: the problem, the actors, the social norms, the nodal points and the processes, whose configuration produces different types of governance, and, therefore, of citizenship. Likewise, Natera (2005) mentions that both social capital and public leadership are specific decisive conditions to guarantee the success of the governance which he conceives as governmental action, referring to the management of networks integrated by a multiplicity of public and private actors who interact in a complex way and whose analysis receives preferential attention.

\section{Context of the Sabinal River and Sumidero Canyon sub-basins}

Chiapas is one of the states with greatest water resources in Mexico, with a contribution of $40 \%$ of the country total. In $2005,71.1 \%$ of the inhabited private households had piped water (SEDESOLINEGI, 2005), proportion that increased to $73.5 \%$ in 2010 (INEGI, 2010); this represents a minimal increase $(2.4 \%)$, quite below the growth of the demand. In this state there are springs that run out of water for long periods of time, and rural women of low income are the ones most affected because they must carry it to their homes. The lack of water is also associated to deforestation, soil degradation, pollution, and overexploitation of the aquifers. Facing this situation, Land Regulation Programs (Programas de Ordenamiento Territorial, POET) have been implemented, as well as emergency plans, such as in the case of the Sabinal River sub-basin (Gobierno del Estado de Chiapas, 2010).

The Sabinal River sub-basin is a source of water supply for human consumption in Tuxtla Gutiérrez, the capital of Chiapas, city that has 553,374 
La Subcuenca Río Sabinal es fuente de abastecimiento de agua para consumo humano de Tuxtla $\mathrm{Gu}-$ tiérrez, la capital de Chiapas, ciudad que cuenta con 553374 habitantes y ha registrado un crecimiento acelerado en la última década (INEGI, 2010). También existen razones ecológicas para procurar su conservación, dado que en el área de la Subcuenca Río Sabinal se encuentran relictos de bosque mesófilo de montaña que están confinados a estrechas zonas altitudinales de las regiones montańosas, donde con frecuencia existen nubes a la altura de la vegetación. Dentro de las subcuencas Río Sabinal y Cañón del Sumidero se encuentra el Área Natural Protegida estatal con categoría de Zona Sujeta a Conservación "La Pera", que forma parte del corredor biológico Cañón del Sumidero-Selva "El Ocote", integrado por otras áreas protegidas, como el Parque Nacional Cañón del Sumidero, la Zona de Protección Forestal Villa Allende, la Zona Sujeta a Conservación Ecológica Laguna Bélgica y la Reserva de la Biosfera Selva El Ocote (SEMAHN, 2015). El corredor Cañón del Sumidero-Selva El Ocote permite la continuación de vínculos ecológicos funcionales, así como la dispersión genética natural (Gobierno del Estado de Chiapas 2010).

La Subcuenca Cañón del Sumidero pertenece a la Cuenca Río Grijalva, donde se ubican las presas La Angostura, Chicoasén, Nezahualcóyotl y Peñitas, que aportan $23 \%$ de la energía eléctrica utilizada en el país. Sin embargo, la sustentabilidad de los recursos hídricos es amenazada por la desigualdad en la disponibilidad de agua, los asentamientos urbanos desordenados, la degradación de las cuencas, la sobreexplotación de los mantos acuíferos y los efectos del cambio climático. Esta subcuenca cuenta con una superficie aproximada de 6700 kilómetros cuadrados, distribuidos en 16 municipios, y constituye la principal fuente de recursos hídricos utilizados en los sectores agrícola, turístico y urbano (Gobierno del Estado de Chiapas 2010:190).

\section{MATERIAL Y MÉTODOS}

Se analizó la gobernanza con base en la teoría de Hufty (2004), conocida como Marco Analítico de Gobernanza (MAG), para abordar cinco unidades analíticas: problemas, puntos nodales, actores, normas y procesos. Estos procesos de gobernanza se analizaron en torno a los sectores gubernamentales que participan en los comités, juntas y estrategias para inhabitants and has presented an accelerated growth in the last decade (INEGI, 2010). There are also ecological reasons to seek its conservation, given that in the area of the Sabinal River sub-basin there are relicts of mountainous cloud forest that are confined to narrow altitudinal zones of the mountainous regions, where there are frequently clouds at the height of the vegetation. Within the Sabinal River and Sumidero Canyon sub-basins there is the "La Pera" state Natural Protected Area with category of Zone Subject to Conservation, which is part of the Sumidero Canyon-"El Ocote" Rainforest biological corridor, integrated by other protected areas, such as the Sumidero Canyon National Park, the Villa Allende Forest Protection Zone, the Laguna Bélgica Zone Subject to Ecological Conservation and the "El Ocote" Biosphere Reserve (SEMAHN, 2015). The Sumidero Canyon-"El Ocote" Rainforest corridor allows the continuation of functional ecological connections, as well as natural genetic dispersion (Gobierno del Estado de Chiapas 2010).

The Sumidero Canyon sub-basin belongs to the Grijalva River Basin, where the La Angostura, Chicoasén, Nezahualcóyotl and Peñitas dams are located, which contribute $23 \%$ of the electrical energy used in the country. However, the sustainability of the water resources is threatened by the inequality in water availability, disordered urban settlements, degradation of basins, overexploitation of aquifers, and effects from climate change. This sub-basin has an approximate surface of 6700 square kilometers, distributed in 16 municipalities, and constitutes the main source of water resources used in the agricultural, tourism and urban sectors (Gobierno del Estado de Chiapas 2010:190).

\section{MATERIAL AND METHODS}

Governance was analyzed based on the theory by Hufty (2004), known as Governance Analytical Framework (GAF), to address five analytical units: problems, nodal points, actors, norms and processes. These governance processes are analyzed around the government sectors that participate in the committees, boards and strategies for the conservation of water resources and the sustainable management of water in the Sabinal River and Sumidero Canyon sub-basins in the state of Chiapas during the period 2014-2015. 
la conservación de los recursos hídricos y el manejo sustentable del agua en las subcuencas Río Sabinal y Cañón del Sumidero en el estado de Chiapas durante el periodo 2014-2015.

La investigación se realizó en cuatro etapas:

1) Análisis de los problemas del agua en la cuenca. Se consultó información secundaria, bibliográfica y cartográfica de la cuenca en bases de datos (SEDESOL-INEGI, 2005; COLPOS, 2010).

2) Entrevistas a informantes clave que conocen el manejo del agua y las cuencas en la zona de estudio. Para identificar a los actores y sus procesos se realizaron entrevistas semiestructuradas, con preguntas abiertas sobre los problemas del agua, su participación en grupos de trabajo para la solución de conflictos y los principales acuerdos. Se entrevistó a las siguientes autoridades: municipales (Director de Fomento Agropecuario, directivo de Sistema de Agua Potable y Alcantarillado de Berriozábal), estatales (funcionarios de la Secretaría de Medio Ambiente e Historial Natural: Coordinador de investigación, especialista de la Coordinación de Investigación, Director de Áreas Naturales y Vida Silvestre, analista encargado del Área Natural Protegida Estatal La Pera) y federales (Director del Parque Nacional Cañón del Sumidero, Director y técnicos de la Zona de Protección Forestal Villa Allende y Director de la Comisión Nacional del Agua en Chiapas).

3) Puntos nodales y sus normas. Las entrevistas ayudaron a conocer los espacios donde se discute la problemática del agua y los servicios ecosistémicos de las cuencas. Se analizaron las normas mediante consulta de documentos rectores.

4) Percepciones de las personas entrevistadas en relación con la gobernanza del agua y la participación social, apartado que contribuye a explicar los procesos de gobernanza percibidos desde las instituciones involucradas.

\section{RESULTADOS Y DISCUSIÓN}

\section{Contexto normativo-institucional}

Las iniciativas de atención a los problemas de degradación de la Subcuenca Río Sabinal se delimitan en tres documentos rectores: Estudio de Aprovechamiento Hidráulico Integral y de Control de Inundaciones
The research was carried out in four stages:

1) Analysis of the water problems in the basin. Secondary, bibliographic and cartographic information from the basin was consulted in databases (SEDESOL-INEGI, 2005; COLPOS, 2010).

2) Interviews with key informants who understand water management and the basins in the study zone. To identify the actors and their processes, semi-structured interviews were performed, with open questions about water problems, their participation in work groups for the solution of conflicts and the main agreements. The following authorities were interviewed: municipal (Director of Agricultural and Livestock Promotion, director of the Drinking Water System and Drainage of Berriozábal), state (officials from the Ministry of the Environment and Natural History: research coordinator, specialist from the Research Coordination, Director of Natural Areas and Wild Life, analyst in charge of La Pera State Natural Protected Area), and federal (Director of the Sumidero Canyon National Park, director and technicians from the Villa Allende Zone of Forest Protection and Director of the National Water Commission in Chiapas).

3) Nodal points and their norms. The interviews helped to understand the spaces where the quandary of water and the ecosystemic services in the basins are discussed. The norms were analyzed through a consult of guiding documents.

4) Perceptions of the people interviewed in relation to water governance and social participation, section that contributes to explain the governance processes perceived from the institutions involved.

\section{RESULTS AND DISCUSSION}

\section{Normative-institutional context}

The initiatives of attention to problems of degradation of the Sabinal River sub-basin are defined in three guiding documents: Study of Integrated Water Exploitation and Flooding Control of the Sabinal River Basin (Gobierno del Estado de Chiapas, 2004), Program of Territorial Ecological Planning of the Sub-basin (Gobierno del Estado de Chiapas, 2010), and Management and Integrated 
de la Cuenca Río Sabinal (Gobierno del Estado de Chiapas, 2004), Programa de Ordenamiento Ecológico Territorial de la Subcuenca (Gobierno del Estado de Chiapas, 2010) y Plan de Gestión y Manejo Integral de la Subcuenca Río Sabinal (COLPOS, 2010), que exponen lo prioritario de frenar el cambio de uso de suelo y revertir los indicadores de deterioro ambiental mediante acciones de conservación y restauración ambiental (Gordillo et al., 2012).

En 2004, el Gobierno del estado de Chiapas encargó a la Universidad Autónoma de Chiapas la elaboración del estudio de Aprovechamiento Hidráulico Integral y de Control de Inundaciones de la Cuenca del Río Sabinal, teniendo como origen las inundaciones ocurridas el 25 de junio de 1996 y el 6 de octubre de 2003. En esta última, la inundación abarcó aproximadamente seis kilómetros del Río Sabinal y en algunas zonas el agua alcanzó una altura de dos metros y medio. Fue la peor inundación sufrida por la ciudad de Tuxtla Gutiérrez (Gordillo et al., 2012:14); por ello, constituye un importante precedente en el conocimiento hidráulico de la cuenca $y$, derivado de esto, plantea escenarios y alternativas de solución para evitar o disminuir los riesgos de las inundaciones, determinando la solución óptima desde el punto de vista ingenieril y con acciones estructurales. Asimismo, se reconoce la necesidad de abordar la problemática con alternativas no estructurales, como: aprovechamiento sustentable de los acuíferos, control del cambio de uso de suelo, y conservación y restauración de las áreas de bosque (Gobierno del Estado de Chiapas, 2004).

En 2010 el Gobierno del Estado decretó el Programa de Ordenamiento Ecológico Territorial de la Subcuenca Río Sabinal (POET, 2010). En él se describe el estado actual de los subsistemas de la cuenca (natural, económico y social) y se reconoce que en $20 \%$ del territorio es necesario implementar una política para la restauración desde los enfoques de conservación y aprovechamiento sustentable. Por la metodología del instrumento, elaborado con la participación de actores clave y mediante consulta pública, es considerado ejemplo de instrumentos legales derivados de un proceso participativo. Actualmente, el documento está en proceso de actualización, debido al acelerado cambio de uso de suelo que ha sufrido la subcuenca en los últimos cinco años.

El Plan de Gestión y Manejo Integral de la Subcuenca Río Sabinal es el primer esfuerzo que pone de
Management Plan of the Sabinal River Sub-basin (COLPOS, 2010), which expose the importance of stopping land use change and reverting the indicators of environmental deterioration through actions of environmental conservation and restoration (Gordillo et al., 2012).

In 2004, the governement of the state of Chiapas commissioned the Autonomous University of Chiapas with the elaboration of the study of Integrated Water Exploitation and Flooding Control in the Sabinal River Basin, which originated from the flooding that took place on June 25, 1996, and October 6, 2003. In the latter, the flooding covered approximately six kilometers of the Sabinal River and in some zones the water reached a level of 2.5 meters. It was the worst flooding suffered by the city of Tuxtla Gutiérrez (Gordillo et al., 2012:14); therefore, it constitutes an important precedent in the water knowledge of the basin and, derived from this, it suggests scenarios and alternatives for solution to avoid or decrease the risks of flooding, defining the optimal solution from the engineering point of view and with structural actions. Likewise, the need to address the quandary with non-structural alternatives, such as: sustainable exploitation of aquifers, control of land use change, and conservation and restoration of forest areas (Gobierno del Estado de Chiapas, 2004).

In 2010 the Government of the State decreed the Program of Territorial Ecological Planning of the Sabinal River Sub-basin (POET, 2010). The current state of the basin's sub-systems is described in it (natural, economic and social), and it is recognized that in $20 \%$ of the territory it is necessary to implement a policy for restoration from the approaches of conservation and sustainable exploitation. Because of the methodology of the instrument, elaborated with the participation of key actors and through public consult, it is considered an example of legal instruments derived from a participative process. Presently, the document is being updated, due to the accelerated change in land use experienced by the sub-basin in the last five years.

The Management and Integrated Management Plan of the Sabinal River Sub-basin is the first effort that demonstrates the need to address environmental deterioration with the basin approach, based on acause, condition and effect scheme. The recommendation of developing a program of environmental rescue emerges from this, accompanied by productive and 
manifiesto la necesidad de atender el deterioro ambiental con el enfoque de cuencas, a partir de un esquema de causa, condición y efecto. De aquí surge la recomendación de desarrollar un programa de rescate ambiental, acompańado de proyectos productivos y económicos, con la premisa de conservación de suelo y agua y, en lo posible, que estos sean consensuados con la población y autoridades gubernamentales (COLPOS, 2010).

En atención a los documentos rectores de la cuenca, y considerando que aún falta camino para internalizar el costo y la importancia del aporte de ecosistemas al manejo integrado de la Cuenca Río Sabinal, en agosto de 2011 se integró el grupo de trabajo especializado o "mesa de restauración", encargado de auxiliar al Comité de Cuenca Río Sabinal en la toma de decisiones.

Se continuó con una etapa de planeación estratégica, a fin de que la mesa de restauración y el Comité dispusieran de un instrumento de planeación operativa para la restauración hidrológico-ambiental, a instancias de la Oficina de Gerencia de Cuenca Río Sabinal y el proyecto "Estrategia para la restauración y rehabilitación de la cuenca Río Sabinal: Un enfoque ecosistémico para la conservación y manejo sustentable de la biodiversidad asociada a las cuencas hidrográficas de Chiapas", coordinado por la Secretaría de Medio Ambiente e Historia Natural, y la concurrencia de instituciones y usuarios implicados en proyectos y prácticas de restauración. Con esta iniciativa se comenzó a dar respuesta a las inquietudes de la "Mesa de Restauración" de analizar, reconocer y aplicar acciones que tiendan a revertir los indicadores de degradación ambiental en la cuenca (Gordillo et al., 2012).

\section{Degradación de la cuenca por urbanismo acelerado/caótico/mal planeado: El caso de la colonia Ciudad Maya en Berriozábal, Chiapas}

De las entrevistas a funcionarios del Sistema de Agua Potable y Alcantarillado del Municipio de Berriozábal (SAPAM) se desprende que una de las principales problemáticas de la región es la ampliación de la mancha urbana hacia Berriozábal. Tal es el caso de la colonia Ciudad Maya, que con la remunicipalización quedó ubicada en Berriozábal. Actualmente, esta colonia demanda servicios de agua entubada al municipio que antes surtía la empresa constructora. economic projects, with the premise of soil and water conservation and, if possible, for these to be agreed upon with the population and governmental authorities (COLPOS, 2010).

According to the guiding documents of the basin, and taking into consideration that there is still a way to go in order to internalize the cost and importance of the contribution of ecosystems to the integrated management of the Sabinal River Basin, in August 2011 the specialized work group or "restoration table" was integrated, in charge of aiding the Sabinal River Basin Committee in decision making.

Next, there was a stage of strategic planning, in order for the restoration table and the Committee to have an instrument for operative planning for the hydrological-environmental restoration, at the request of the Management Office of the Sabinal River Basin and the project "Strategy for the restoration and rehabilitation of the Sabinal River Basin: An ecosystemic approach for the conservation and sustainable management of biodiversity associated to hydrographic basins in Chiapas", coordinated by the Ministry of the Environment and Natural History, and the concurrence of institutions and users implicated in projects and practices for restoration. With this initiative we began to respond the concerns from the "Restoration Table" of analyzing, recognizing and applying actions that tend to reverse the indicators of environmental degradation in the basin (Gordillo et al., 2012).

\section{Degradation of the basin from accelerated/ chaotic/ill-planned urbanism: The case of the Ciudad Maya neighborhood in Berriozábal, Chiapas}

From the interviews with officials of the Drinking Water and Drainage System of the municipality of Berriozábal (Sistema de Agua Potable y Alcantarillado del Municipio, SAPAM), it can be deduced that one of the main problems of the region is the growth of the urban sprawl toward Berriozábal. Such is the case of the Ciudad Maya neighborhood, which was located in Berriózabal with re-munizipalization. Presently, this neighborhood demands piped water services from the municipality that supplied the building company before. In Ciudad Maya there are approximately 2400 households, with a population of 10000 residents. Until today, in this neighborhood 
En Ciudad Maya existen aproximadamente 2400 viviendas, con una población de 10000 habitantes. Hasta la fecha, en esta colonia solo se han realizado 146 contratos de agua; al elaborar el contrato se pagan dos mil pesos y mensualmente se comprometen a pagar 200 pesos. SAPAM surte de pipas a las personas con las que tiene contrato y proporciona 8800 litros al mes por familia, con un costo de 0.025 pesos/litro de agua. Los habitantes sin contrato compran pipas de agua a particulares, con un costo más elevado, por ejemplo, 400 pesos por 4400 litros.

Personal de SAPAM instaló un módulo de atención en Ciudad Maya, con la finalidad de inscribir a las personas interesadas en realizar contratos de agua, pero fueron detenidos por algunos habitantes de la colonia, que no los querían dejar salir hasta que se comprometieran a abastecerlos de agua. Para evitar este tipo de incidentes se retiró el módulo de atención y ahora los pobladores de Ciudad Maya deben dirigirse a las oficinas del SAPAM en Berriozábal.

Una de las soluciones planteadas para abastecer de agua a la cabecera municipal de Berriozábal es la operación de la obra hidráulica "Brazo Norte", donde el Sistema Municipal de Agua Potable y Alcantarillado de Tuxtla Gutiérrez (SMAPA) iniciará el suministro de agua potable para el municipio de Berriozábal.

En 2011, el entonces gobernador Juan Sabines Guerrero inauguró las obras "Ciudad del Agua" en Tuxtla Gutiérrez y "Brazo Norte” en Berriozábal, con el objetivo de abastecer de agua a los habitantes del centro y norte de Tuxtla Gutiérrez, y de 13 colonias y ocho barrios de Berriozábal; la inversión fue de más de mil 100 millones de pesos (La Jornada, 21 de diciembre de 2011). Sin embargo, a casi cinco años no se ha logrado operar el "Brazo Norte". Ya concluyó el periodo de pruebas de hermeticidad e hidrostática para limpiar las tuberías y próximamente se iniciará el abastecimiento. Por medio del Brazo Norte el SMAPA llevará agua al tanque "La Carreta" -ubicado en el ejido Plan de Ayala, en la salida poniente de Tuxtla Gutiérrez-, y desde ahí el ayuntamiento de Berriozábal la bombeará hacia ese municipio. El tanque tiene una capacidad de 15 mil metros cúbicos y para suministrar el agua a través de una línea de conducción que llega a la cabecera municipal de Berriozábal, el ayuntamiento firmará un convenio con la Comisión Federal de Electricidad (CFE). Este proyecto requerirá que el SMAPA reprograme el suministro: "un tandeo adecuado" para que llevar agua a only 146 water contracts have been signed; when elaborating the contract, two thousand pesos are paid and a commitment is made to pay 200 pesos monthly. SAPAM supplies pipes to the people that it has a contract with, and provides 8800 liters per month per family, with a cost of 0.025 pesos/liter of water. The residents without contract purchase water pipes from private companies, with a higher cost, for example, 400 pesos for 4400 liters.

Staff from SAPAM installed a service module in Ciudad Maya, with the aim of registering the people interested in signing water contracts, but they were stopped by some residents in the neighborhood, who did not want to let them leave until they committed to supplying water. To avoid this type of incidents the service module was withdrawn and now the inhabitants of Ciudad Maya must go to the SAPAM offices in Berriozábal.

One of the solutions suggested to supply water to the municipal township of Berriozábal is the operation of the hydraulic work "Brazo Norte", where the Municipal System of Drinking Water and Drainage (Sistema Municipal de Agua Potable y Alcantarillado, SMAPA) of Tuxtla Gutiérrez will begin with the drinking water supply for the municipality of Berriozábal.

In 2011, the then governor Juan Sabines Guerrero inaugurated the works "Ciudad del Agua" in Tuxtla Gutiérrez and "Brazo Norte" in Berriozábal, with the objective of supplying water to the inhabitants in the center and north of Tuxtla Gutiérrez, and in 13 neighborhoods and eight boroughs of Berriozábal; the investment was more than 1.1 billion pesos ( $\mathrm{a}$ Jornada, December 21, 2011). However, after nearly five years the "Brazo Norte" has not been managed to be operated. The period of impenetrability and hydrostatic tests to clean the pipes has concluded, and soon the supply will begin. Through the Brazo Norte, the SMAPA will take water to the "La Carreta" tank -located in the Plan de Ayala ejido, in the western exit of Tuxtla Gutiérrez-, and from there the local government of Berriozábal would pump it toward the municipality. The tank has a capacity of 15 thousand cubic meters and to supply water through a conducting line that reaches the municipal township of Berriozábal, the local government will sign an agreement with the Commission of Federal Electricity (Comisión Federal de Electricidad, CFE). This project would require the SMAPA to reprogram 
Berriozábal no represente un problema de desabasto en Tuxtla Gutiérrez.

Como una alternativa para atender la problemática de abasto de agua para los habitantes de Ciudad Maya, el funcionario de SAPAM menciona lo siguiente:

"Cuando opere el Brazo Norte y llegue el agua a la cabecera municipal de Berriozábal se podría poner una tubería que llegue hasta el tanque de almacenamiento de Ciudad Maya, pero esto requerirá una fuerte inversión y no creo que los habitantes de Ciudad Maya estén dispuestos a pagarla”.

Respecto al impacto ambiental que este tipo de obras podría generar en los ecosistemas, uno de los entrevistados comenta:

"El Brazo Norte resolvería parcialmente el problema de abasto de agua en Berriozábal, pero el agua que se traerá de la "Ciudad del Agua» de Tuxtla proviene de los ríos Suchiapa y Santo Domingo, que son de las subcuencas más deterioradas, y podría terminar con los servicios ecosistémicos de donde se originan” (Biol. Adrián Méndez Barrera, Director CONANP).

\section{PUNTOS NODALES DONDE SE DISCUTE LA PROBLEMÁTICA DE LOS RECURSOS HÍDRICOS EN LAS SUBCUENCAS RÍO SABINAL Y CAÑÓN DEL SUMIDERO}

\section{Comisión de Cuenca Cañón del Sumidero}

Desde 2005 se creó la Comisión de Cuenca de Cañón del Sumidero, que a la fecha solo ha sesionado tres veces. Con base en los testimonios se cuestiona que los organismos de Cuenca Cañón del Sumidero y Río Sabinal tengan la capacidad y los recursos para resolver una problemática tan grande. Algunos entrevistados opinan que debido a esta desarticulación no se ha avanzado en la problemática de contaminación por residuos sólidos del área natural protegida de carácter federal Parque Nacional Cañón del Sumidero:

"Hubo una reunión de la Comisión de Cuenca Cañón del Sumidero. En la mesa redonda estaban los representantes de las instituciones estatales y federales, y los usuarios de la Cuenca fueron the supply: "an adequate batch system" so that taking water to Berriozábal does not represent a lack of supply in Tuxtla Gutiérrez.

As an alternative to address the quandary of water supply for the inhabitants of Ciudad Maya, the SAPAM official mentions the following:

"Once the Brazo Norte operates and the water reaches the municipal township of Berriozábal, piping could be installed to reach the supply tank of Ciudad Maya, but this would require a strong investment and I don't think that the residents of Ciudad Maya would be willing to pay it".

Regarding the environmental impact that this type of works could generate in the ecosystems, one of the interview respondents mentions:

"The Brazo Norte would partially solve the problem of water supply in Berriozábal, but the water that would be brought from the "City of Water" of Tuxtla comes from the Suchiapa and Santo Domingo rivers, which are the most deteriorated sub-basins, and could finish off the ecosystemic services from where they are originated" (Biol. Adrián Méndez Barrera, Director of CONANP).

\section{NODAL POINTS WHERE THE QUANDARY OF WATER RESOURCES IS DISCUSSED IN THE SABINAL - RIVER AND SUMIDERO CANYON SUB-BASINS}

\section{Sumidero Canyon Basin Commission}

Since 2005 the Sumidero Canyon Basin Commission was created, which up to date has only been in session three times. Based on the testimonies, it is questioned whether the agencies of the Sumidero Canyon Basin and Sabinal River have the capacity and the resources to solve such a big quandary. Some interview respondents are of the opinion that due to this disarticulation, there has been no advancement in the problem of pollution by solid residues in the federal national protected area Sumidero Canyon National Park:

"There was a meeting of the Sumidero Canyon Basin Commission. At the round table there were 
acomodados en otras sillas, atrás de la mesa. Desde el simple acomodo de los participantes, desde ahí das poco valor a la participación de la gente sentada al margen de la mesa" (Biólogo Adrián Méndez Barrera, Funcionario de CONANP).

Sobre la contaminación del agua en el Cañón del Sumidero, el entrevistado comenta:

"Los datos no son confiables y son muy variables. Se puede decir que se manipulan a conveniencia, por ejemplo, cuando se realizan las competencias de natación los datos de contaminación del agua bajan” (Biólogo Adrián Méndez Barrera, funcionario de CONANP).

La percepción es que CONAGUA no asume las atribuciones que le corresponden, como en el caso de la limpieza de los residuos sólidos en el Cañón del Sumidero:

"A pesar de que de los primos de la SEMARNAT, CONAGUA recibe más recursos, seguida de CONAFOR, luego PROFEPA, y al último CONANP; la CONANP ha invertido más de tres millones de pesos al ańo en limpiar la contaminación por residuos sólidos en el Cañón del Sumidero y por esto deja de hacer otras actividades que sí le corresponden” (Biólogo Adrián Méndez Barrera, funcionario de CONANP).

"Existe una autoridad fáctica, pero no práctica, que es la CONAGUA. Es necesaria una gestión integrada que incluya los servicios ecosistémicos" (Biólogo Froilán Esquinca Cano, Coordinador de Investigación Técnica, SEMAHN).

"En este sexenio la política no es apoyar a los comités de cuenca”. (M. C. Mercedes Gordillo, especialista de la Coordinación de Investigación, SEMAHN).

Las personas entrevistadas coinciden en que CONAGUA no realiza las funciones que le corresponden, aunque funcionarios de la Comisión mencionan que existen instrumentos como el Plan de Manejo Integral de la Cuenca Cañón del Sumidero y el Plan de Gestión y Manejo Integral de la Cuenca Río Sabinal, documentos de planeación que rigen a representatives from state and federal institutions, and the users of the Basin were placed in other chairs, behind the table. From the simple arrangement of participants, from there, you are giving less value to the participation of people sitting on the edge of the table" (Biol. Adrián Méndez Barrera, Official of CONANP).

Regarding water pollution in the Sumidero Canyon, the interview respondent said:

"The data are not reliable and are quite variable. It can be said that they are manipulated at convenience, for example, when swimming competitions are held, the water pollution data decrease" (Biol. Adrián Méndez Barrera, Official of CONANP).

The perception is that CONAGUA does not take on the attributions that correspond to it, as in the case of cleaning solid residues in the Sumidero Canyon:

"Although they are cousins to SEMARNAT, CONAGUA receives more resources, followed by CONAFOR, then PROFEPA, and lastly CONANP; the CONANP has invested more than three million pesos per year in cleaning pollution from solid residues in the Sumidero Canyon and that is why it ceases to perform other activities that do correspond to it" (Biol. Adrián Méndez Barrera, funcionario de CONANP).

"There is a factual authority, but not practical, which is CONAGUA. An integrated management is necessary that includes ecosystemic services" (Biol. Froilán Esquinca Cano, Technical Research Coordinator, SEMAHN).

"In this six-year term the policy is not to support the basin committees". (M. Sc. Mercedes Gordillo, specialist of the Research Coordination, SEMAHN).

The people interviewed agree that CONAGUA does not perform the functions that correspond to it, although officials from the Commission mention that there are instruments as the Integrated Management Plan of the Sumidero Canyon Basin and the 
la Comisión de Cuenca del Cañón del Sumidero y al Comité de Cuenca Río Sabinal, respectivamente. Ambos planes se dividen en seis objetivos: disminuir los daños por fenómenos meteorológicos; adecuado aprovechamiento de los recursos forestales; disminuir la contaminación de suelo, agua y bosque; fortalecimiento del desarrollo agropecuario; mejora de agua potable y alcantarillado, y mejora del hábitat sociocultural.

Debido al poco seguimiento y participación de los integrantes de la Comisión de Cuenca Cañón del Sumidero fue necesario buscar un nuevo mecanismo para resolver el problema de la contaminación por residuos sólidos; así surge la iniciativa de la Junta Intermunicipal del Cañón del Sumidero.

\section{Contaminación por residuos sólidos en el Cañón del Sumidero: El caso de la iniciativa Junta Intermunicipal para la Cuenca Cañón del Sumidero (JICCAS)}

El organismo público descentralizado "Junta Intermunicipal para la Cuenca Cañón de Sumidero" (JICCAS) fue creado el 27 de noviembre de 2014 (Periódico Oficial no. 152 del estado de Chiapas). La iniciativa de gestión municipal para atender problemas sobre residuos sólidos nace en Francia, donde surge el concepto de gestión y resolución de problemas mediante la agrupación de municipios.

En México, con base en esta iniciativa, se han obtenido resultados favorables en la cuenca del Río Ayuquila y Armada, con la Junta Intermunicipal de Río Ayuquila en el estado de Jalisco. La JICCAS es una iniciativa similar, adecuada a las condiciones de Chiapas, que involucra a los tres niveles de gobierno, la sociedad y la iniciativa privada. Se pretende lograr: 1) la participación activa y real de los municipios a largo plazo, sin importar orientaciones políticas ni cambio trianual en los gobiernos locales; 2) la continuidad de proyectos, recursos humanos y financieros; 3) que los municipios tomen decisiones en función del manejo integrado de cuenca y de las necesidades regionales (con ayuda técnica especializada se da orientación y se prioriza en acciones para la solución de problemas relacionados con la conservación de la cuenca y el mantenimiento de servicios ecosistémicos, como agua, paisaje y prevención de desastres); y 4) atender problemas de residuos sólidos urbanos y rurales.
Management and Integrated Management Plan of the Sabinal River Basin, documents for planning that regulate the Sumidero Canyon Basin Commission and the Sabinal River Basin Committee, respectively. Both plans are divided into six objectives: decrease damages from meteorological phenomena; adequate exploitation of forest resources; decrease the pollution of soil, water and forest; strengthen agriculture and livestock development; improve drinking water and drainage; and improve sociocultural habitat.

Due to the scarce follow-up and participation of the members of the Sumidero Canyon Basin Commission, it was necessary to search for a new mechanism to solve the problem of contamination from solid residues; thus, the initiative of the Intermunicipal Board of the Sumidero Canyon Basin.

\section{Contamination from solid residues in the Sumidero Canyon: The case of the Inter-municipal Board of the Sumidero Canyon Basin (JICCAS) initiative}

The decentralized public agency "Inter-municipal Board of the Sumidero Canyon Basin" (Junta Intermunicipal para la Cuenca Cañón de Sumidero, JICCAS) was created on November 27, 2014 (Official Newspaper no. 152 of the state of Chiapas). The initiative of municipal management to address problems of solid residues arose in France, where the concept of management and problem resolution through the grouping of municipalities arose.

In Mexico, based on this initiative, favorable results have been obtained in the Ayuquila River and Armada Basin, with the Inter-municipal Board of Ayuquila River in the state of Jalisco. The JICCAS is a similar initiative, adapted to the conditions of Chiapas, which involves the three levels of government, society and the private sector. The following are the aims to be achieved: 1) active and real participation of the municipalities in the long term, without regard to political orientations or triannual change in the local governments; 2) continuity of projects, human and financial resources; 3) that municipalities make decisions in function of the integrated management of the basin and regional needs (with specialized technique, direction and priority are given to actions for the solution of problems related to conservation of the basin and maintenance of ecosystemic services, such as water, landscape and disaster prevention); 
El Cañón del Sumidero enfrenta un problema específico de contaminación por residuos sólidos que se incrementa cada temporada de lluvias; proviene de 15 municipios que conforman la cuenca media del Río Grijalva y la Subcuenca del Río Sabinal: Tuxtla Gutiérrez, Chiapa de Corzo, Berriozábal, San Fernando, Villa Flores, Villa Corzo, Acalá, Chiapilla, Venustiano Carranza, Totolapa, San Lucas, Veinte de Noviembre, Nicolás Ruiz, Ixtapa y Suchiapa.

El objetivo es formar un organismo público descentralizado entre los 15 municipios de la cuenca Cañón del Sumidero que permita dar continuidad a los trabajos de restauración de cuenca, saneamiento de ríos, manejo de residuos sólidos y ambiental. Estos municipios integraron un organismo público descentralizado y un fideicomiso que será alimentado por instancias federales, estatales, municipales y privadas. Entre los beneficios de la JICCAS destacan: 1) Continuidad: la iniciativa permite realizar proyectos de mediano y largo plazo, superando las gestiones trianuales; 2) Gobernanza: la visión de manejo integral de cuenca promueve el orden entre usuarios de la cuenca y se enfoca a proyectos estratégicos ambientales; 3) Recursos: los recursos de las JICCAS serán operados de forma transparente, a través de un fideicomiso, y observados por la comisión de cuencas y los organismos de la Junta; 4) Economía: se impulsa el desarrollo de economía de escala, a través del turismo y el manejo integral de los residuos.

Los testimonios revelan lo siguiente:

"Las JICCAS tendrán sus fortalezas y debilidades, debido a que no participan todos los municipios involucrados. Lo importante sería que dentro de la JICCA se adoptara la estrategia de restauración para que esta tenga instrumentos de planeación, gestión y programación porque si no serían esfuerzos aislados" (Gordillo et al., 2012).

Acerca de la gobernanza del agua en la Subcuenca Río Sabinal y Cañón del Sumidero, los y las entrevistadas opinan que:

"Falta una nueva gobernanza para hacer frente a los obstáculos en la gestión del agua con voluntad política, recursos humanos calificados y transparencia” (Biólogo Froilán Esquinca Cano, Coordinador de Investigación, SEMAHN). and 4) addressing problems of urban and rural solid residues.

The Sumidero Canyon faces a specific problem of contamination from solid residues that increases each rainy season; it comes from 15 municipalities that make up the medium basin of the Grijalva River and the Sabinal River Sub-basin: Tuxtla Gutiérrez, Chiapa de Corzo, Berriozábal, San Fernando, Villa Flores, Villa Corzo, Acalá, Chiapilla, Venustiano Carranza, Totolapa, San Lucas, Veinte de Noviembre, Nicolás Ruiz, Ixtapa and Suchiapa.

The objective is to form a decentralized public agency among the 15 municipalities of the Sumidero Canyon Basin that allows giving continuity to the basin restoration works, river sanitation, management of solid residues and the environment. These municipalities integrated a decentralized public agency and a trusteeship that would be financed by federal, state, municipal and private instances. Among the benefits of the JICCAS, the following stand out: 1) Continuity: the initiative allows performing medium and long term projects, surpassing triannual administrations; 2) Governance: the vision of integrated management of the basin promotes the order between basin users and focuses on strategic environmental projects; 3) Resources: the resources from JICCAS will be operated transparently, through a trusteeship, and observed by the basin commission and the agencies of the Board; 4) Economy: the development of scale economy is promoted, through tourism and integrated management of residues.

The testimonies reveal the following:

"The JICCAS will have their strengths and weaknesses, because not all the municipalities involved participate. The important issue would be that the strategy of restoration could be adopted within the JICCA, for it to have instruments of planning, management and programming, because otherwise they would be isolated efforts" (Gordillo et al., 2012).

Regarding water governance, in the Sabinal River and Sumidero Canyon sub-basin, the interview respondents are of the opinion that:

"A new kind of governance is lacking to face the obstacles in water management with political will, qualified human resources and transparency" 
"La gobernanza está sujeta a ciclos políticos que son dinámicos. Habría que explorar dentro del marco legal de la LAN que se pudieran dejar fuera estas limitantes, ya que con el cambio de diputados y presidentes municipales y la veda electoral no podemos reunirnos a hablar de temas técnicos" (Mercedes Gordillo, especialista de la Coordinación de Investigación, SEMAHN).

\section{MESA DE RESTAURACIÓN DEL COMITÉ DE CUENCA DEL RÍO SABINAL}

\section{Estrategia para la restauración hidrológico- ambiental de la Subcuenca Río Sabinal 2011-2021 (ERSABI)}

La Estrategia para la restauración hidrológico-ambiental de la Subcuenca Río Sabinal 2011-2021 forma parte del proyecto "Estrategias para la restauración y rehabilitación de la cuenca del Río Sabinal: Un enfoque ecosistémico para la conservación y manejo sustentable de la biodiversidad asociada a las cuencas hidrográficas de Chiapas", que fue financiado con los fondos mixtos COCYTECH-CONACYT.

En una visión de largo plazo (al 2021) y a través de la ERSABI, los actuales gobiernos con incidencia en el territorio podrán: "contribuir a la restauración hidrológica ambiental de la Cuenca del Río Sabinal mediante la rehabilitación y regeneración natural de los ecosistemas, desde la valoración de los servicios ecosistémicos, articulando instituciones y estimulando la participación social”.

La ERSABI plantea objetivos, líneas y acciones estratégicas para coadyuvar en la prevención de las amenazas, la atención de los factores causales y los efectos de deterioro ambiental dirigidos a procurar la recuperación de los ecosistemas, a fin de que estos continúen proveyendo los servicios y bienes, fundamentalmente aquellos cuya naturaleza provee bienes a la sociedad y regula procesos funcionales en los ecosistemas estrechamente relacionados con el bienestar humano. Acerca de los problemas que enfrenta el entendimiento del concepto restauración, se comenta:

"Es necesaria una buena comprensión de los actores en el tema. Confunden reforestación con restauración; en una cuenca la reforestación apoya, pero su aporte es limitado. La estrategia debe bajar de escala a los usuarios y poderla contextualizar.
(Biol. Froilán Esquinca Cano, Research Coordinator, SEMAHN).

"Governance is subject to political cycles that are dynamic. Within the legal framework of the LAN, it should be explored that these limitations be left aside, since with the change in representatives and municipal presidents, and the electoral closed season, we cannot meet to talk about technical issues" (Mercedes Gordillo, specialist from the Research Coordination, SEMAHN).

\section{RESTORATION TABLE OF THE SABINAL RIVER BASIN COMMITTEE}

\section{Strategy for the hydrological-environmental restoration of the Sabinal River Sub-basin 2011-2021 (ERSABI)}

The Strategy for the hydrological-environmental restoration of the Sabinal river Sub-basin 2011-2021 is part of the project "Strategies for the restoration and rehabilitation of the Sabinal River Basin: An ecosystemic approach for the conservation and sustainable management of biodiversity associated to hydrographic basins in Chiapas", which was financed with the COCYTECH-CONACYT mixed funds.

In a long-term vision (to 2021) and through ERSABI, the current governments with influence in the territory could: "contribute to the hydrological environmental restoration of the Sabinal River Basin through the rehabilitation and natural regeneration of the ecosystems, from the valuation of ecosystemic services, articulating institutions and stimulating social participation".

The ERSABI suggests objectives, lines and strategic actions to contribute in the prevention of threats, the attention to causal factors, and the effects of environmental deterioration directed at attaining the recovery of ecosystems, with the aim of these continuing to supply goods and services, fundamentally those whose nature provides goods to society and regulates functional processes in the ecosystems that are closely related to human welfare. About the problems faced in understanding the concept of restoration, the following is mentioned:

"A good comprehension about the theme by actors is necessary. They confuse reforestation with restoration; in a basin reforestation helps, but its 
También es necesario incidir a nivel de funcionarios para obtener financiamiento, debido a que las subcuencas Río Sabinal y Cañón del Sumidero no son áreas prioritarias; es necesario posicionarlas como prioritarias a esos niveles" (Mercedes Gordillo, especialista de la Coordinación de Investigación, SEMAHN).

\section{DISCUSIÓN}

En este estudio se identificaron las dificultades de llevar a cabo una coordinación de actores y sectores que permita un manejo del agua desde la gobernanza (Lemos y Agraval, 2006). Una gobernabilidad sustentable del agua debe integrar un amplio rango de actores y Lebel et al. (2006) señala que esto se consigue cuando los actores comparten y ejercen el poder. El análisis de los procesos de gobernanza del agua en las subcuencas Río Sabinal y Cañón del Sumidero revela que aún son incompletos, particularmente en lo que se refiere a las estrategias participativas, la aplicación de la normatividad y la ejecución de una toma de decisiones consensuada, pero sobre todo en la implementación de estrategias. De acuerdo con Domínguez (2011), es un hecho que no todo recae en el marco legal, y la oposición que se presenta en las reglas formales que se encuentran en la ley, en las reglas informales provenientes de acuerdos sociales e incluso de las autoridades está provocando conflictos sociales por el manejo del agua. Si bien es cierto que se crean espacios de concertación y deliberación, estos no consiguen involucrar a todos los actores relevantes y no se consideran las normas establecidas formalmente en la toma de decisiones. Tampoco se logran dirimir los conflictos que emergen de la confrontación de sistemas de gestión del agua establecidos a diferentes escalas administrativas y espaciales. Por ejemplo, con respecto a la escasez de agua en las localidades rurales, en Berriozábal existe una organización comunitaria (Gutiérrez et al., 2013a) y una participación social para tomar acuerdos en la gestión del agua mediante los comités comunitarios de agua, donde se encontró poca participación de mujeres $(\mathrm{Gu}-$ tiérrez et al., 2013b). La única instancia gubernamental que participa en este nivel local es el municipio y su intervención se reduce a la dotación de cloro. Retamal et al. (2013) mencionan que existe un incremento de demandas sociales que exigen mayor participación transformadora en la gobernanza del agua y que el concepto de participación es el elemento clave que contribution is limited. The strategy should lower the scale to users and be able to contextualize it. There is also the need to have an impact at the level of officials to obtain financing, because the Sabinal River and Sumidero Canyon sub-basins are not priority areas; it is necessary to position them as priority at those levels" (Mercedes Gordillo, specialist of the Research Coordination, SEMAHN).

\section{DISCUSSION}

In this study the difficulties of carrying out a coordination of the actors and sectors that allow water management based on governance are identified (Lemos and Agraval, 2006). A sustainable governability of water should integrate a broad range of actors, and Lebel et al. (2006) point out that this is achieved when actors share and exert power. The analysis of water governance processes in the Sabinal River and Sumidero Canyon sub-basins reveals that they are still incomplete, particularly in what refers to participative strategies, the application of normativity, and the execution of consensual decision making, but above all in the implementation of strategies. According to Domínguez (2011), it is a fact that not everything depends on the legal framework, and that the opposition presented in the formal rules that are found in the law, in the informal rules from social agreements and even from the authorities, is causing social conflicts over water management. Although it is true that spaces for concertation and deliberation are created, these do not manage to involve all the actors relevant and the norms established formally in decision making are not considered. The conflicts that emerge from the confrontation of water management systems, established at different administrative and spatial scales, are also not settled. For example, concerning water scarcity in rural localities, in Berriozábal there is a community organization (Gutiérrez et al., 2013a) and social participation to make agreements in water management through community committees for water, where low participation of women was found (Gutiérrez et al., 2013b). The sole government instance that participates at this local level is the municipality and its intervention is reduced to providing chloride. Retamal et al. (2013) mention that there is an increase of social demands that require 
debe definirse entre los diversos sistemas/actores que conforman el proceso de la gobernanza, el cual está estrechamente relacionado con el nivel de comprensión sobre la dinámica socio-ecológica de las cuencas del país. Asimismo, el caso del suministro de agua para las zonas urbanas de reciente creación, como el de la colonia Ciudad Maya, plantea una problemática de gobernanza diferente: se toman decisiones entre dos sistemas de agua potable, el de Berriozábal y el de Tuxtla, para la compra de agua que será distribuida por el "Brazo Norte". Sin embargo, estos acuerdos no se concretan ni existe consenso con la ciudadanía respecto a los costos que tendrán que pagar por este servicio, y tampoco se visualiza el impacto ambiental que genera el traer el agua de otra cuenca degradada. El caso ejemplifica cómo la toma de decisiones consensuadas entre entes gestores del agua mantiene una estrategia de exclusión de la ciudadanía, usuaria del agua o que, al menos, no contempla a los usuarios como grupo decisor legítimo.

Finalmente, el problema relacionado con el deterioro físico de la cuenca tiene cuatro puntos nodales: el Comité de Cuenca Río Sabinal, la Comisión de Cuenca del Cañón del Sumidero, la Mesa Interinstitucional para Resolver la Problemática de Tierra de Hoja y, de reciente creación, la Junta Intermunicipal del Cañón del Sumidero (JICA), conformada por 16 municipios, donde se pretende resolver la problemática de contaminación por residuos sólidos del Área Natural Protegida Parque Nacional Cañón del Sumidero, lo que concuerda con el modelo de Junta Intermunicipal para la Gestión Integral de la Cuenca Baja del Río Ayuquila (JIRA), donde no debe perderse de vista la parte burocrático-administrativa (Zamora, 2011) y que, de acuerdo con Ruiz et al. (2010), es un proceso de gobernanza a nivel regional que posee fortalezas como el área geográfica, que abarca el poder de interacción de 10 municipios, la capacidad de gestionar y hacerse respetar, así como su unión para afrontar un problema común en el Río Ayuquila en Jalisco.

De acuerdo con González Franco (2013), las juntas intermunicipales de medio ambiente son una plataforma interinstitucional en la que deliberan los gobiernos municipales con representantes de dependencias federales y estatales; por lo tanto, el municipio juega un papel importante en la implementación de políticas públicas para la conservación y el uso sostenible dentro del capital natural de país (Graf et al., 2009), a través de una política de descentralización more transforming participation in water governance and that the concept of participation is the key element that should be defined between the various systems/actors that make up the governance process, which is closely related to the level of comprehension about the socio-ecological dynamics of the country's basins. Likewise, the case of water supply for urban zones of recent creation, such as that in the Ciudad Maya neighborhood, suggests a different governance problem: decisions are made between two drinking water systems, the one in Berriozábal and the one in Tuxtla, for the purchase of water that would be distributed by the "Brazo Norte". However, these agreements are not crystallized, nor is there consensus with citizens with regards to the costs that they will have to pay for this service, and the environmental impact is also not visualized generated by bringing water from another deteriorated basin. The case exemplifies how consensual decision making between water management entities maintains a strategy of exclusion of citizens, the water users or which, at least, does not contemplate users as a legitimate decision making group.

Finally, the problem related to physical deterioration of the basin has four nodal points: the Sabinal River Basin Committee, the Sumidero Canyon Basin Commission, the Inter-institutional Table to Solve the Problem of Tierra de Hoja, and of recent creation, the Inter-municipal Board of the Sumidero Canyon (JICA), made up of 16 municipalities, where the quandary of contamination from solid residues at the Sumidero Canyon Natural Protected Area is attempted to be resolved, which agrees with the model of the Inter-municipal Board for Integrated Management of the Ayuquila River Low Basin (JIRA), where the bureaucratic-administrative part should not be overlooked (Zamora, 2011) and which, according to Ruiz et al. (2010), is a governance process at the regional level that has strengths such as the geographic area, including the power of interaction of 10 municipalities, the capacity to manage and attain respect, as well as their union to face a common problem in the Ayuquila River in Jalisco.

According to González Franco (2013), the inter-municipal environmental boards are an inter-institutional platform in which municipal governments deliberate with representatives from federal and state agencies; therefore, the municipality 
de la gestión pública que les otorga nuevas funciones (León et al., 2007).

Entre las fortalezas de la actual gobernanza del agua en las subcuencas de estudio, pueden mencionarse: la existencia de un marco normativo, el incremento de información integrada que sustenta la toma de decisiones, y la promoción de iniciativas de coordinación intersectorial e interinstitucional, lo que coincide con lo hallado en Chile por Retamal et al. (2013). Sin embargo, también se observa un marco normativo para prevenir el deterioro ambiental de esta cuenca, como son el estudio de Aprovechamiento Hidráulico Integral y de Control de Inundaciones de la Cuenca Río Sabinal, el Programa de Ordenamiento Ecológico Territorial de la Subcuenca, y el Plan de Gestión y Manejo Integral de la Subcuenca Río Sabinal; y se tiene una Comisión de Cuenca del Cañón del Sumidero y un Consejo de Cuenca del Río Sabinal que debe tener una visión integral del manejo de los recursos hídricos, espacios que no han tenido la presencia suficiente y no han logrado los resultados esperados.

De acuerdo con González Franco (2013), muchas políticas públicas e instrumentos de gestión para la función gubernamental han fracasado. Caso conspicuo es el ordenamiento ecológico territorial (OET), que ha fallado como ejercicio de construcción de acuerdos entre los actores de un territorio acerca de los usos que habrán de darse al suelo y el acceso a los recursos, y los servicios que proveen los ecosistemas en el territorio, principalmente por haberlo reducido a un ejercicio técnico de cartografía. En este sentido, se observa una característica de otros esquemas de gobernanza compartida: se logra una articulación en la fase de planificación de estrategias de acción que recoge el enfoque de manejo integrado de cuencas, así como la definición de acciones conjuntas, pero no se supera la barrera de la implementación conjunta.

Parte de los obstáculos para la implementación de las estrategias recogidas en documentos de planificación conjunta tienen que ver con capacidades técnicas y gerenciales que atiendan; además, ejes de acción transversal que fortalezcan y garanticen una gestión integral y compartida del agua, como son: promoción de programas de educación ambiental, cultura del agua, protección de los suministros, control de la erosión y las inundaciones, así como fomento de la valoración de los servicios ecosistémicos que prestan estas subcuencas, entre ellos la provisión de agua y la regulación climática. plays an important role in the implementation of public policies for the conservation and sustainable use within the natural capital of the country (Graf et al., 2009), through a decentralization policy of public management that grants them new functions (León et al., 2007).

Among the strengths of the current water governance in the sub-basins of study, the following can be mentioned: the existence of a normative framework, the increase of integrated information that sustains decision making, and the promotion of inter-sectorial and inter-institutional coordination initiatives, which agrees with what was found in Chile by Retamal et al. (2013). However, a normative framework is also observed to prevent the environmental deterioration of this basin, as in the study of Integrated Water Exploitation and Flooding Control of the Sabinal River Basin, the Ecological Planning Program of the Sub-basin, and the Management and Integrated Management Plan of the Sabinal River Sub-basin; and there is a Sumidero Canyon Basin Commission and a Sabinal River Basin Council that must have an integral vision of water resources management, spaces that have not had sufficient presence and have not achieved the results expected.

According to González Franco (2013), many public policies and management instruments for government function have failed. A conspicuous case is territorial ecological planning (ordenamiento ecológico territorial, OET), which has failed as an exercise of construction of agreements between the actors of a territory regarding the uses that should be given to land and access to resources, and the services that ecosystems provide in the territory, mainly from having been reduced to a technical exercise of cartography. In this sense, a characteristic of other shared governance schemes is observed: an articulation is achieved in the planning phase of strategies for action that the approach of integrated management of basins collects, as well as the definition of joint actions, but the barrier of joint implementation is not outdone.

Some of the obstacles for the implementation of strategies gathered in joint planning documents have to do with the technical and managerial capacities that they address; in addition, axes of transversal action that strengthen and ensure an integrated and shared management of water, such as: promotion of environmental education programs, water culture, 
Asimismo, aunque existen espacios donde se reúnen actores clave para resolver ciertos problemas, la participación ha sido condicionada al financiamiento de los proyectos y, si bien se han logrado documentos rectores con propuestas interesantes, como la Estrategia para la Restauración Hidrológico-Ambiental de la Subcuenca Río Sabinal 2011-2021 (ERSABI) (Gordillo et al., 2012), de nuevo estos instrumentos de planificación innovadores no superan la fase de la planificación. El principal problema para la implementación de estas propuestas radica en que su puesta en práctica implica la cesión de espacios de poder, así como la superación de inercias institucionales de fuerte arraigo. Según González Franco (2013), debido al carácter sectorial del ejercicio del gobierno, muchos de los programas gubernamentales "aterrizan" en el territorio de manera desordenada (por falta de complementariedad, coordinación y sinergia), atomizan los recursos que se otorgan e incluso, en ciertos casos, incentivan prácticas contrapuestas a los objetivos de otras políticas o programas, en vez de bajar de manera integrada e invertirse en procesos efectivos de desarrollo para las comunidades.

Los casos abordados evidencian que la existencia de una estructura normativa e institucional apta para desarrollar planes integrales de manejo del agua, como la que existe en las subcuencas Río Sabinal y Cañón del Sumidero, constituye apenas el primer peldaño en la construcción de procesos de gobernanza del agua integradores e incluyentes.

Estas estrategias de gobernanza sacan a la luz algo ya conocido: la falta de coordinación entre los diferentes niveles de gobierno, la ausencia de integración entre instituciones, y la falta de participación ciudadana real y efectiva, especialmente de actores locales rurales, lo cual deriva en la ausencia de un manejo integrado de la cuenca con una visión ecosistémica que repercuta en un uso sustentable y a la vez equitativo del agua. Esto implica ceder poder político y económico desde la esfera gubernamental a las arenas de interacción de actores definidas en la ley, con fines de coordinación y participación. La política del agua debe partir del reconocimiento del funcionamiento ecosistémico e interdependiente con los demás elementos naturales, y ser inclusiva de todos los actores porque afecta a la sociedad directamente (Domínguez, 2011).

El actor clave que podría inclinar la balanza hacia una visión más integral en la gestión del agua es protection of supplies, erosion and flooding control, as well as promotion of the assessment of ecosystemic services that these sub-basins provide, among them the provision of water and climate regulation.

Likewise, although there are spaces where key actors gather to solve certain problems, the participation has been conditioned to project financing and, although regulation documents with interesting proposals have been achieved, such as the Strategy for the Hydrological-Environmental Restoration of the Sabinal River Sub-basin 20112021 (ERSABI) (Gordillo et al., 2012), again these new innovative planning instruments do not surpass the planning phase. The main problem for the implementation of these proposals lies in the fact that putting them into practice implies the cession of power spaces, as well as overcoming institutional inertias of strong rooting. According to González Franco (2013), because of the sectorial character of the government exercise, many of the government programs "land" in the territory in an unorganized way (from lack of complementarity, coordination and synergy), they atomize the resources that are given and, even, in certain cases, stimulate practices opposing the objectives of other policies or programs, instead of decreasing in an integrated manner and investing in effective processes of development for the communities.

The cases approached evidence that the existence of a normative and institutional structure that is apt for developing integrated water management plans, such as those present in the Sabinal River and Sumidero Canyon sub-basins, constitute barely the first step in the construction of water governance processes that are integrating and inclusive.

These governance strategies bring to light something that is already known: the lack of coordination between the different levels of government, the absence of integration between institutions, and the lack of real and effective citizen participation, especially of local rural actors, which derives into the absence of an integrated management of the basin with an ecosystemic vision that has an effect on the sustainable and at the same time equitable use of water. This implies relinquishing political and economic power from the government sphere to the interaction arenas between actors defined in the law, with the purposes of coordination and participation. The water policy should emerge from the recognition 
la Comisión Nacional del Agua (CONAGUA), ente rector en la toma de decisiones respecto al manejo del agua. Sin embargo, sus acciones se basan en un enfoque que privilegia la construcción de estructuras hidráulicas de alto costo y fuerte impacto en la dinámica funcional de los ciclos hidrológicos. No se plantea combinar esta visión con el enfoque ecosistémico; al contrario, la canalización e impermeabilización de riberas como control de inundaciones en el Río Sabinal y en otros del estado de Chiapas (Ruiz de Oña, 2014), así como la provisión de agua a partir de obras de ingeniería de dimensiones importantes, como la construcción del trasvase del "Brazo Norte", son las opciones preferenciales.

A pesar de la persistente retórica en torno a la necesidad de un manejo integral de cuenca, sustentable y participativo, no parece que se comprenda qué significa ni cómo realizarlo. Tampoco parece fomentarse el valor de la funcionalidad del ecosistema, de forma que mantenga la base del recurso agua, su regeneración y suministro a futuro.

Si no se resuelve esta percepción de la problemática en los actores involucrados, no será posible lograr la conservación de las cuencas y de los servicios ecosistémicos que estas proveen. De igual forma, si no se trabaja en pos de la construcción de procesos de participación ciudadana, los avances que puedan darse en términos de una gestión más eficiente e integrada también quedarán en entredicho.

\section{CONCLUSIÓN}

Los casos abordados en este estudio ejemplifican las dificultades que enfrentan los procesos de gobernanza del agua en entornos que ya cuentan con una estructura institucional establecida para tal fin. A pesar de la existencia de espacios típicamente asociados a un régimen de gobernanza deliberativa e inclusiva, predominan las prácticas de interacción entre actores vinculadas a un régimen jerárquico administrativo, donde unos ejecutan y otros definen el qué se debe ejecutar. Estos espacios acaban refuncionalizándose en plataformas donde la toma de decisiones queda restringida a la discusión sobre el reparto de recursos y posicionamiento político, y donde las soluciones de corte técnico predominan sobre aquellas que tienen que ver con la inclusión de otros saberes, especialmente los conocimientos empíricos derivados de la práctica cotidiana e histórica del manejo del agua a of the ecosystemic and interdependent functioning with the other natural elements, and it should be inclusive of all the actors because it affects society directly (Domínguez, 2011).

The key actor that could tip the scales toward a more integrated vision in water management is the National Water Commission (Comisión Nacional del Agua, CONAGUA), governing entity in decision making regarding water management. However, its actions are based on an approach that privileges the construction of hydraulic structures of high cost and strong impact on the functional dynamics of water cycles. It is not proposed that this vision be combined with the ecosystemic approach; on the contrary, the channeling and waterproofing of riverbanks as flood control in the Sabinal River and others in the state of Chiapas (Ruiz de Ońa, 2014), as well as the provision of water from engineering works of important dimensions, such as the construction of the "Brazo Norte" diversion, are the preferred options.

Despite the persistent rhetoric around the need of an integrated management of the basin, that is sustainable and participative, there doesn't seem to be understanding of what it means or how to do it. There also doesn't seem to be encouragement of the value of ecosystem functionality, so that the base of the water resource is maintained, as well as its regeneration and supply in the future.

If this perception of the quandary in the actors involved is not solved, it will not be possible to achieve the conservation of basins and the ecosystemic services that these provide. Likewise, if there is no work done in favor of the construction of processes of citizen participation, the advances that can happen in terms of a more efficient and integrated management will also be questionable.

\section{CONCLUSION}

The cases addressed in this study exemplify the difficulties that water governance processes face in environments that already have an institutional structure established for that purpose. Despite the existence of spaces typically associated to a deliberative and inclusive governance regime, the practices of interaction between actors linked to an administrative hierarchical regime predominate, where some execute and others define what should be done. These spaces end up being refunctionalized 
nivel local, que podrían alimentar y ser base de políticas públicas de corte más incluyente y diversificado.

El estudio revela que la gobernanza del agua como ejercicio concreto de articulación de actores públicos y privados va mucho más allá del entramado institucional y de la confluencia puntual de un conjunto de actores en un espacio, bajo una regulación específica: en el proceso de articulación de actores emergen invariablemente prácticas de hacer política y desbalances de poder que desde el discurso de la gobernanza suelen quedar opacados. De ahí que el objetivo principal de una práctica de gobernaza necesita apuntar a la formación de procesos de interacción de actores diversos que caminen hacia una reestructuración democrática de la cultura política. De lo contrario, bajo el discurso prevaleciente de la participación e inclusión de actores diferentes del gobierno, lo que al final prevalece, es una simulación de práctica política y la prevalencia de históricos desquilibrios en la toma de decisiones.

Finalmente añadiremos que, como dispositivo heurístico, los marcos conceptuales de gobernanza, tal y como se aplica en este estudio, no permiten abordar en profundidad la riqueza y complejidad de las experiencias locales de manejo del agua, cuya estructura y trayectoria histórica desborda los márgenes analíticos de la gobernanza. Sería necesario completar estos marcos analíticos con una conceptualización específica para las experiencias locales, de base antropológica y etnográfica.

\section{Agradecimiento}

Al Consejo Nacional de Ciencia y Tecnología (CONACyT) por la beca de otorgada para realizar una estancia de investigación posdoctoral.

\section{LITERATURA CITADA}

Aguilar, F. Luis. 2007. El aporte de la política pública y de la nueva gestión pública a la gobernanza. In: Reforma y Democracia, 39, Caracas, CLAD, octubre.

Arts, B., y P. Leroy. 2006. Institutional Dynamics in Environmental Governance, Dordrech, Países Bajos, Springer.

Bäckstrand, K. 2010. Environmental Politics and Deliberative Democracy: Examining the Promise of New Modes of Governance, Edward Elgar Publishing.

Borquez Kesler, María A., Elizabeth Guerrero Cavides, y María A. Alegría Calvo. 2007. Levantamiento y análisis de información sobre institucionalidad para transversalizar el género en la gestión del agua en algunos países de América Latina, Santiago de Chile, UNESCO, Centro de Estudios de la in platforms where decision making is restricted to the discussion about resource distribution and political positioning, and where technical solutions predominate over those related with the inclusion of other knowledge, especially empirical understanding derived from the daily and historical practice of water management at the local level, which could inform and be the basis of public policies of a more inclusive and diversified nature.

The study reveals that water governance as a concrete exercise of the articulation of public and private actors goes far beyond the institutional fabric and the punctual confluence of a set of actors in a space, under a specific regulation: in the articulation process of actors, practices of policy making and power imbalances invariably emerge which, from the governance discourse, tend to be overshadowed. From this that the main objective of a practice of governance needs to point to the formation of interaction processes of various actors that move toward a democratic restructuring of political culture. On the contrary, under the prevalent discourse of participation and inclusion of actors other than government, in the end that which prevails is a simulation of political practice and the prevalence of historical imbalances in decision making.

Finally, we will add that, as heuristic mechanism, the conceptual framework of governance, as is applied in this study, does not allow approaching in depth the wealth and complexity of local experiences of water management, whose structure and historical trajectory exceeds the analytical margins of governance. It would be necessary to complete these analytical frameworks with a specific conceptualization for local experiences, of anthropological and ethnographic basis.

- End of the English version-

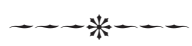

Mujer, 99 p. [Consultado en: www.unesco.org.uy/phi/ayg/ informe-final-cem/ultima-version-pdf].

Briggs, S. 2003. Command and control in natural resource management: Revisiting Holling and Meffe. Ecological Management \& Restoration, 4(3):161-162.

COLPOS (Colegio de Postgraduados). 2010. Plan de Manejo y Gestión Integral de la Cuenca Río Sabinal, México, CONAGUA, 120 p.

Domínguez, Judith, Anabel Palacios Moreno, Carolina Diana Martínez, Alejandro Jaime Vences Mejía, José Luis Torres Ortega, Pedro Ulises Carranza González, David Robles Hernández, Lydia Meade Ocaranza, Carolina Salcedo García, 
Daniel Licea Murillo, Roberto Olivares, Jorge Montoya Suárez, Laura Elizabeth Ortiz Domínguez, y Elisa Kochskaemper. 2012. Hacia un posicionamiento de gobernanza del agua en México, México, El Colegio de México, Comisión Nacional del Agua (CONAGUA), Instituto Mexicano de Tecnología del Agua (IMTA), ANEAS. Documento revisado en el Foro de Marsella a Río, 29 de mayo de 2012, México, AYESA, 105 p.

Domínguez, S.J. 2007. La gobernanza del agua en México y el reto de la adaptación en zonas urbanas: El caso de la ciudad de México. Anuario de Estudios Urbanos, México, UAMAzcapotzalco.

Domínguez, S.J. 2011. Obstáculos para una gobernanza efectiva del agua en México. Estudio de la Región Hidrológica X Golfo Centro en Retos de la Investigación del Agua en México, México, CONAGUA-El Colegio de México.

García, Antonino. 2010. Instituciones y pluralismo legal: La hidropolítica en la cuenca transfronteriza Grijalva (19502010), México, El Colegio de la Frontera Sur, 383 p.

Gobierno del Estado de Chiapas. 2004. Estudio de Aprovechamiento Hidráulico Integral y de Control de Inundaciones de la Cuenca Río Sabinal, México, Universidad Autónoma de Chiapas.

Gobierno del Estado de Chiapas. 2010. Programa de Ordenamiento Territorial de la Subcuenca Río Sabinal (POET) en los municipios de San Fernando, Berriozábal, Ocozocuautla de Espinoza y Tuxtla Gutiérrez. In: Periódico Oficial, 223, Secretaría General de Gobierno, Tuxtla Gutiérrez, México, p. 135-191. [Consultado en: http://www.semarnat.gob.mx/temas/ordenamientoecologico/Documents/documentos $\% 20$ decretados/decretos_2010/decreto_sabinal.pdf].

González Franco de la Peza, Rafael. 2013. La gobernanza intermunicipal y la implementación de mecanismos REDD+ a nivel local, México, Comisión Nacional Forestal (CONAFOR).

Gordillo, R. M., E. J. F. Santos, y C. F. Esquinca. 2012. Estrategia de Restauración Hidrológico-Ambiental de la Subcuenca Río Sabinal, México, Tuxtla Gutiérrez, Chiapas, Secretaría de Medio Ambiente e Historia Natural, 94 p.

Graf M., Sergio, E. Santana, A. Pizano, y A. Zamora. 2009. Gobernanza para el desarrollo territorial en el contexto de manejo de cuencas: El caso del Río Ayuquila. In: J. T. Padilla López, S. Graf Montero, E. Santana Castellón (comps), Alternativas para una nueva gobernanza social: Intermunicipalidad y desarrollo territorial, México, Universidad de Guadalajara, Jalisco.

Gutiérrez Villalpando Verónica, Austreberta Nazar Beutelspacher, Benito Salvatierra Izaba, Emma Zapata Martelo, y Julio Contreras Utrera. 2013a. Mujeres y organización social en la gestión del agua para consumo humano y uso doméstico en Berriozábal, Chiapas. In: Revista LIMINAR Estudios Sociales y Humanísticos, México, Centro de Estudios Superiores de México y Centroamérica-Universidad de Ciencias y Artes de Chiapas, año 11, vol. XI, núm. 2, julio-diciembre.

Gutiérrez Villalpando Verónica, Austreberta Nazar Beutelspacher, Benito Salvatierra Izaba, Emma Zapata Martelo, y Julio Contreras Utrera. 2013b. Género y participación de las mujeres en la gestión del agua en las subcuencas Río Sabinal y Cañón del Sumidero en Berriozábal, Chiapas. In: Revista de Estudios de Género La Ventana, núm. 38, México, Uni- versidad de Guadalajara, julio-diciembre.

Holg, Karl, Eva Kvarda, Ralf Nordbeck, y Michael Pregernig 2012. Legitimacy and effectiveness of environmental governance: Concepts and perspectives. In: K. Hogl, Eva Kvarda, Ralf Nordbeck y Michael Pregernig (eds), Environmental Governance, Cheltenham, UK, Northampton, MA, USA, Edward Elgar.

Holley, C., N. Gunningham, and C. Shearing. 2011. The New Environmental Governance, Routledge.

Holling, C. S., and G. K. Meffe. 1996. Command and Control and the Pathology of Natural Resources Management. Conservartion Biology, 10(2). pp: 328-37.

Hufty, Mark. 2004. Marco conceptual de la gobernanza. Una propuesta para concretizar el concepto de la gobernanza, Instituto Universitario de Estudios del Desarrollo, Ginebra.

INEGI (Instituto Nacional de Estadística y Geografía). 2010. Censo General de Población y Vivienda, México.

Kallis, G., M. Kiparsky, and R. Norgaard. 2009. Collaborative governance and adaptive management: Lessons from California's CALFED Water Program. Env. Sci. Policy, 12:631-643.

Kooiman, J. 2004. Gobernar en Gobernanza. In: Instituciones y Desarrollo, España, Institut Internacional de Governabilitat de Catalunya, núm. 16, pp: 171-194.

Lebel, L., J. M. Anderies, B. Campbell, C. Folke, S. HatfieldDodds, T. P. Hughes, and J. Wilson. 2006. Governance and the capacity to manage resilience in regional social-ecological systems. Ecol. Soc, 11:19.

Lemos, M. C., and A. Agrawal. 2006. Environmental governance. Annu. Rev. Env. Resourc, 31:297-325.

León, D., J. Sosa, y M. S. Graf. 2007. Alianzas intermunicipales en México: Alternativas y ejemplos para la descentralización. In: J. Fraga, G. J. Villalobos, S. Doyon y A. García (eds), Gobernanza costera en México: Descentralización y manejo ambiental en la península de Yucatán, México, Universidad Autónoma de Campeche, Plaza y Valdés.

Martínez, Austria P. F., y Reyna Guzmán F. 2012. Gobernanza: Reflexiones desde la gestión pública. In: Daniel Licea Murillo (coord), La gobernanza del agua. Un desafío actual. Hacia una mirada crítica del concepto y de su aplicación, México, Jiutepec, Morelos, Instituto Mexicano de Tecnología del Agua, pp: 17-38.

Mayntz, R. 2001. El Estado y la sociedad civil en la gobernanza moderna. In: Reforma y Democracia, CLAD, núm. 21, octubre, pp: 1-22.

Murillo Licea, Daniel. 2012. La trampa de la gobernanza del agua. Problemas del traslado del concepto a la aplicación. In: Daniel Murillo Licea (coord), La gobernanza del agua. Un desafío actual. Hacia una mirada crítica del concepto y de su aplicación, México, Jiutepec, Morelos, Instituto Mexicano de Tecnología del Agua, pp: 79-113.

Natera Peral, Antonio. 2005. Nuevas estructuras y redes de gobernanza. Revista Mexicana de Sociología, octubre-diciembre, 755-791.

Newig, J., J. P. Voß, and J. Monstadt. 2007. Governance for Sustainable Development in the Face of Ambivalence, Uncertainty and Distributed Power: an Introduction. Journal of Environmental Policy \& Planning, 9, septiembre-diciembre, pp: $185-192$.

OCDE (Organización para la Cooperación y el Desarrollo Eco- 
nómicos). 2011. Water Governance in OECD Countries: A Multi-level Approach, París, OECD Studies on Water.

Ostrom, E. 2000. El Gobierno de los bienes comunes. La evolución de las instituciones de acción colectiva, México, CRIM/ UNAM-FCE.

Paz Salinas, Ma. Fernanda. 2012. Conflictos socioambientales, cultura política y gobernanza: La cooperación bajo sospecha. In: L. Durand, F. Figueroa y M. Guzmán (eds), La naturaleza en contexto. Hacia una ecología política mexicana, México, CEIICH, CRIM, COLSAN.

Rhodes, R. A. 1996. The New Governance: Governing Without Government. Political Studies, XLIV, pp: 652-667.

Retamal, M., Andreoli, A., Arumi, J., Rojas, J., y Parra, O. 2013. Gobernanza del agua y cambio climático: fortalezas y debilidades del actual sistema de gestión del agua en Chile. Análisis interno. Interciencia, 38 (1), 8-16.

Ruiz de Ońa, Plaza Celia. 2014. Ciudad y adaptación al cambio climático: navegando por literaturas de ecología política urbana. In: Sociedad y Ambiente, año 2, vol. 1, núm. 5, juliooctubre de 2014, pp: 115-132.

Ruiz Salcido, S. Guerritsen, Peter R.W., y R. L. M. Martínez 2010. Gobernanza del agua a nivel local: Estudio de caso en el municipio de Zapotitlán de Vadillo, Jalisco. In: EL Cotidiano, México, UAM-Xochimilco, 89 p. [Consultado en: http://popul.xoc.uam.mx].
SEDESOL (Secretaría de Desarrollo Social), Instituto Nacional de Estadística y Geografía (INEGI). 2005. Delimitación de las zonas metropolitanas de México.

SEMAHN (Secretaría de Medio Ambiente e Historia Natural del Estado de Chiapas). 2015. Programa de Manejo Zona Sujeta a Conservación Ecológica La Pera. febrero, 81 p.

SEMARNAT (Secretaría de Medio Ambiente y Recursos Naturales). 2004. Ley de Aguas Nacionales. In: Diario Oficial de la Federación, 29 de abril de 2004.

Vargas Velázquez, Sergio, y Roberto Romero Pérez. 2008. La gobernanza del agua en la Cuenca del Río Balsas: Resultados de la aplicación de la prueba piloto de la encuesta a los involucrados en la gestión local del agua, México, Jiutepec, Morelos, Instituto Mexicano de Tecnología del Agua.

Waylen, G. 2008. Gendering Governance. In: G. Goertz y A. Mazur (eds), Politics, Gender and Concepts: Theory and Methodology, Cambridge University Press, pp: 114-135.

White, D. D., E. A. Corley, M. S. White. 2008. Water manager's perceptions of the science-policy interface in Phoenix, Arizona: Implications for an emerging boundary organization. In: Soc. Nat. Resourc, 21:230-243.

Zamora, Alonso. 2011. Descripción del procedimiento jurídicoadministrativo de creación del OPDI, denominado: Junta intermunicipal de Medio Ambiente para la Gestión Integral de la Cuenca Baja del Río Ayuquila (JIRA), documento técnico.

Zurbriggen, C. 2011. Gobernanza: Una mirada desde América Latina. In: Perfiles latinoamericanos, 19(38), pp: 39-64. 
